Nig. J. Biotech. Vol. 37(2): 165-176 (Dec. 2020)

ISSN: 01891731

Available online at

http://www.ajol.info/index.php/njb/index

and www.biotechsocietynigeria.org

DOI: https://dx.doi.org/10.4314/njb.v37i2.17

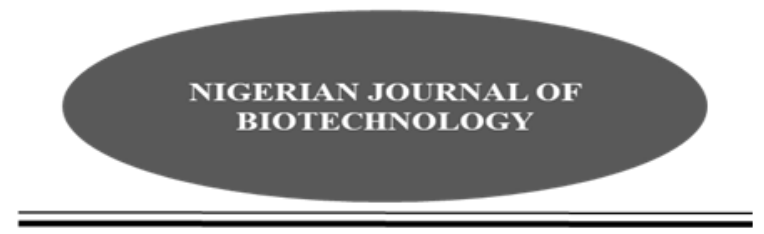

\title{
Screening and Characterization of Biosurfactant-Producing Bacillus Species Isolated from Contaminated Soils in Makurdi Metropolis
}

\author{
John, W.C., ${ }^{1 *}$ Ogbonna, I.0., ${ }^{2}$ Gberikon, G.M., ${ }^{2}$ and Iheukwumere, C.C.., ${ }^{3}$ \\ ${ }^{1}$ Department of Science Laboratory Technology, Federal college of Forestry, Jos, Nigeria. \\ ${ }^{2}$ Department of Microbiology, University of Agriculture, Makurdi, Nigeria. \\ ${ }^{3}$ Department of Botany, Federal University of Agriculture, Makurdi, Nigeria
}

\begin{abstract}
Biosurfactants synthesized by microorganisms are chemically diverse and have gained interest industrially due to their surface and interfacial tensions-reducing activities. In this study Bacillus species from contaminated soils were screened and characterized for biosurfactant production. The study was carried out at the Microbiology Laboratory, Federal University of Agriculture Makurdi, Nigeria. The Bacillus species were isolated from kerosene shops, palm oil shops, nearby restaurants, mechanic workshops and abattoir effluentscontaminated soil samples collected from Makurdi metropolis. The Bacillus spp. were screened for biosurfactants production potentials using various screening methods (oil spreading, beta haemolysis, drop collapse and emulsification index). Specific primers were used to amplify the srfAA (surfactin gene) gene in the Bacillus isolates and the nucleotide sequences were determined at Inqaba Biotec, South Africa. The screening results were statistically analysed using analysis of variance (ANOVA) at $95 \%$ confidence level. Isolate RT7(4)B exhibited the ability to produce biosurfactant, as well as the highest emulsification index (E24) of $73.25 \%$ while isolate PO7(3)C gave the highest oil displacement of 6.77 $\mathrm{mm}$. The supernatant obtained from isolate RT7(4)B showed reduction in surface tension of up to $30.26 \mathrm{mN} / \mathrm{m}$. The isolates gave positive results for biosurfactant production when subjected to drop collapse and Beta haemolytic tests. The Polymerase chain reaction (PCR) results revealed amplifications of srfAA gene from 7 isolates. Based on these findings, the isolates used in this study can be utilized for biosurfactant production, and can also be useful for bioremediation and industrial biotechnology applications.
\end{abstract}

Keywords: Biosurfactants; emulsification index; Bacillus, surface tension; Drop collapse Correspondence: E-mail: jowaltee@gmail.com, Phone number: +2349064487369

Introduction

Global oil spills, generation of waste oils and increased industrial processes have led to huge environmental pollution (Parthipan et al., 2017). Several approaches have been used to address the challenges of environmental pollution among which is microbial remediation (Ismail et al., 2013; Noparat et al., 2014). Biosurfactants which are microbial products play a major role in bioremediation (Sidkey et al., 2016). The demand for biosurfactants has witnessed an upsurge in recent years over the synthetic surfactants due to their low toxicity, biodegradability, effectiveness in bioremediation and stability at extreme $\mathrm{pH}$, salinity and temperature (Desai and Banat, 1997; Akintokun et al., 2017). However, production of biosurfactants are faced with challenges arising 
from their cost of production and low yield of producing strains (Saisa-ard et al., 2013).

In order to obtain potential biosurfactantproducing microorganisms such as Bacillus and Pseudonomas species, utilization of microorganisms and understanding their heterogeneity in the soil community is pivotal (Okore et al., 2017). The use of biosurfactantsynthesizing bacteria from oil- contaminated sites can serve as an excellent tool in biosurfactant production. Bacillus species have been used in many industrial processes ; several studies have implicated them in producing lipopeptide type of biosurfactant (Saisa-ard et al., 2013; Anitha et al., 2015; Okore et al., 2017). Molecular methods are needed to identify the genes required for the synthesis of biomolecules (Shoeb et al., 2015). One of the genes needed for surfactin biosynthesis is a large operon of 25 $\mathrm{kb}$, named $s r f A$, which is also vital for sporulation and competence development (Nakano et al., 1991). The presence of sifA operon and sfp gene is required for the non-ribosomal biosynthesis of surfactin. A srfA operon consists of four genes, SIAAA, SIFAB, SIFAC and SrFAD that make the surfactin synthetase subunits and play a vital role in the proof reading of peptide synthesis (Porob et al., 2013). The srfAA gene conceals phosphopantetheinyl transferase, which plays a part in non-ribosomal biosynthesis of biosurfactant (Cosmina et al., 1993). The srfAA gene transforms the inert protein to active protein to form surfactin synthetase (Pfeifer et al., 2001). The sIfAA found in the SrfA operon plays a major function in the biosynthesis of biosurfactants (Roongsawang et al., 2002).

\section{Materials and Methods}

\section{Collection of Samples}

Soil samples were collected according to the method described by Tambekar and Gadakhl (2013) with little modifications. Briefly, soil samples were randomly collected from kerosene shops, palm oil shops, nearby restaurants, mechanic workshops and abattoir effluent- contaminated soil within Makurdi metropolis. Ten grams $(10 \mathrm{~g})$ of effluentcontaminated soil samples were collected from depths of $5-10 \mathrm{~cm}$ at ten (10) different locations within each of the sample collection sites. The samples were collected using sterile spatula into appropriately labelled sterile polythene bags. The temperatures of the samples were taken immediately before the samples were transferred into an ice pack and transported to the laboratory for analyses.

\section{Isolation of Bacterial Species}

Ten grams of the contaminated soil samples was suspended in $90 \mathrm{~mL}$ of sterile distilled water contained in $100 \mathrm{~mL}$ capacity Erlenmeyer flask and amended with $1 \% \mathrm{v} / \mathrm{v}$ fresh engine oil. The medium was incubated at ambient temperature for 48 hours on a rotary shaker (Model S150, Bartoworld, Scientific, USA) at 150 revolution per minute (rmp). After the incubation, tenfold serial dilution of the samples was carried out using sterile distilled water in test tubes. An aliquot of $1 \mathrm{~mL} \quad$ was poured from the 104 diluted samples into sterile empty Petri dishes, and freshly prepared nutrient agar (Oxoid, UK) at $45-50{ }^{\circ} \mathrm{C}$ was poured into the inoculum. The inoculated media were incubated at $37^{\circ} \mathrm{C}$ for 24 hours. Pure isolates obtained were stored on nutrient agar slants at $4{ }^{\circ} \mathrm{C}$.

\section{Identification of Bacillus Isolates}

Identification of bacterial isolates was carried out according to the methods described by Onyeagba (2004). The microscopic and macroscopic evaluation of the isolates morphology (Gram reaction, spore formation and colony appearance) and presumptive biochemical tests (Catalase, Indole, Oxidase, Urease, Citrate, Nitrate, VP, $\mathrm{H}_{2} \mathrm{~S}$ and Sugars fermentation) were carried out using fresh overnight pure nutrient agar cultures of the isolates.

\section{Preparation of Bacillus Isolates for Biosurfactant Production Screening}

Screening of the Bacillus isolates for biosurfactant production was carried out using $30 \mathrm{~mL}$ nutrient broth in $100 \mathrm{~mL}$ flask inoculated with $3 \% \mathrm{v} / \mathrm{v}$ inoculum of the Bacillus species. The inoculum size $\left(1.5 \times 10^{8} \mathrm{CFU} / \mathrm{mL}\right)$ was determined by comparison with readily prepared McFarland standard 0.5 . The inoculated broth media were incubated on a rotary shaker at $30^{\circ} \mathrm{C}, 150$ rpm for 72 hours. The culture broths were centrifuged (Model 80-213, Germany) at 3000 rpm for 30 minutes to obtain cell-free 
supernatant. The supernatants were collected and tested for emulsification stability, drop collapse and oil spread ability.

\section{Screening of Bacillus Species for Biosurfactant Production}

\section{Emulsification Stability Test (EI24)}

Emulsification stability test was measured according to the method described by Balogun and Fagade (2010). Kerosene (2 mL) was added to $2 \mathrm{~mL}$ supernatant, vortexed for 2 minutes using an electronic vortex machine (Model XH-B, 2012), and kept for 24 hours at ambient temperature. The EI24 index was obtained by dividing the height of the emulsified layer $(\mathrm{mm})$ with the total height of the liquid $(\mathrm{mm})$ and multiplied by 100 . Emulsification stability test of the culture samples was measured after $24 \mathrm{~h}$.

\section{Drop Collapse Assay}

Cell-free broth $(10 \mu \mathrm{L})$ was dispensed in the centre of a drop of vegetable oil (Grand Cereal, Nigeria) on a clean glass slide. After one minute, visual observation of the drops was done. The activity of the collected supernatant was compared with the control (water) as described by Seema and Nakuleshwar (2012).

\section{Oil Spreading Technique}

Distilled water $(20 \mathrm{~mL})$ was dispensed into Petri dish plates. One millilitre of crude oil was dropped in the centre of each of the plates containing the distilled water. This was followed by dispensing $20 \mu \mathrm{L}$ of the supernatant of the culture of Bacillus $\mathrm{sp}$. in the centre of the crude oil drop. Ring formation due to displacement of crude oil was measured using a meter rule. A $20 \mu \mathrm{L}$ distilled water was used as control (Hasham et al., 2012).

\section{Determination of Blood Haemolysis Test}

Sterilized blood agar base was allowed to cool to about $45^{\circ} \mathrm{C}$ and $20 \mathrm{~mL}$ aseptically collected goat blood was added, mixed gently and poured into sterile Petri dishes. About $24 \mathrm{~h}$ freshly grown cultures were aseptically point- inoculated using wire loops at the centre of the blood agar media. The inoculated media were incubated at $37^{\circ} \mathrm{C}$ for
24 hours. The diameters of the clear zones around the colonies were measured using a meter rule (El-Shahawy, 2014).

\section{Surface Tension Reduction}

This was carried out according to the method described by Arezoo and Salmah (2015). Culture broths were centrifuged at $5000 \mathrm{rpm}$ for $30 \mathrm{~min}$ and supernatant collected ; the surface tension of the supernatant was determined using a Tensiometer (Model: Ift-d Rs8, India).

\section{Polymerase Chain Reaction (PCR) Amplification and Gene Sequencing}

DNA extraction was conducted using a commercial kit (QIAquick $®$ Gel Extraction kit, Qiagen, Germany), following manufacturer's instructions. The extracted DNA was used as a template for PCR amplification. Polymerase chain reaction (PCR) amplification of the $16 \mathrm{~S}$ rRNA gene was conducted using the pairs of universal primer 8F:5 AGAGTTTGATCCTGGCTCAG-3 and 1492R:5 GGCTACCTTGTTACGACTT-3; as well as 27F:AGAGTTTGATCMTGGC and 1492R:5GGCTACCTTGTTACGACTT-3 (Sreethar et al., 2014). The nucleotide sequences were determined at Inqaba Biotec, South Africa. The closest matches of the nucleotide sequences were determined by running similarity searches with other deposited DNA sequences on the National Center for Biotechnology Information (NCBI) website using the Basic Local Alignment Search Tool (BLAST). Sequence alignment and phylogenetic analyses were carried out using MEGA version 6.0 (Sreethar et al., 2014).

\section{Polymerase Chain Reaction (PCR) Amplification of Biosurfactant Gene (sIfAA)}

The SIAA gene was amplified using specific primers. PCR mixture components were used according to the manufacturer's (Nippongenetic (Germany)) protocol. The forward and reverse primers: sfpF- 5' ATGAAGATTTACGGAATTTA 3' and sfpR- 5' TTATAAAAGCTCTTCGTACG 3' were used as previously demonstrated by Fateha et al. (2016).

Statistical Analysis of Data 
Means were analysed statistically using ANOVA at $95 \%$ confidence level. Means were separated using Duncan test and data presented in tables.

\section{Results and Discussion}

Among the isolates obtained from the different contaminated soil samples, the potential biosurfactant- producing isolates were confirmed as Bacillus licheniformis, Bacillus subtilis, Bacillus cereus, Bacillus thuringiensis and Lysinibacillus fusiformis by morphological and biochemical characteristics (Table 1). The phenotypic characterization indicated that the Bacillus species are Gram- positive, Rodshaped, non-motile and able to ferment carbohydrates such as glucose, sucrose and galactose (Table 1). The result supported the report of Okore et al. (2017) who isolated Bacillus species from contaminated water samples from different contaminated soils. Previous studies by El-Sheshtawy (2013), Tambekar and Gadakh (2013) and Okore et al. (2013) had revealed the presence of different Bacillus species in oil and non-oil contaminated environments.

Table 1: Biochemical Identification of Bacillus Isolates

\begin{tabular}{|c|c|c|c|c|c|c|}
\hline Reactions & $\begin{array}{l}\text { Bacillus } \\
\text { thuringiensis }\end{array}$ & $\begin{array}{l}\text { Bacillus } \\
\text { subtilis }\end{array}$ & $\begin{array}{l}\text { Bacillus } \\
\text { megaterium }\end{array}$ & $\begin{array}{l}\text { Bacillus } \\
\text { cereus }\end{array}$ & $\begin{array}{l}\text { Bacillus } \\
\text { licheniformis }\end{array}$ & $\begin{array}{l}\text { Lysinibacillus } \\
\text { fusiformus }\end{array}$ \\
\hline Gram & + & + & + & + & + & + \\
\hline Motility & + & + & + & + & + & + \\
\hline $\begin{array}{l}\text { Growth at } \\
25^{\circ} \mathrm{C}\end{array}$ & + & + & + & + & + & + \\
\hline $\begin{array}{l}\text { Parabasal } \\
\text { body }\end{array}$ & + & - & - & - & - & - \\
\hline Urease & + & + & + & + & + & + \\
\hline Oxidase & + & + & + & + & + & + \\
\hline Indole & - & - & - & - & - & - \\
\hline $\mathrm{H}_{2} \mathrm{~S}$ & - & - & - & - & - & - \\
\hline $\begin{array}{l}\text { Starch } \\
\text { hydrolysis }\end{array}$ & + & + & + & + & + & + \\
\hline $\begin{array}{l}\text { Casein } \\
\text { hydrolysis }\end{array}$ & + & + & + & + & + & + \\
\hline Citrate & + & + & + & + & + & + \\
\hline Nitrate & + & + & + & + & + & + \\
\hline VP & + & + & - & + & + & + \\
\hline Gelatin & + & + & + & + & + & + \\
\hline Glucose & + & + & + & + & + & + \\
\hline Mannose & - & + & + & - & + & - \\
\hline Xylose & - & + & - & - & + & - \\
\hline Sorbitol & - & - & Nil & + & Nil & - \\
\hline Rhamnose & - & - & + & + & + & - \\
\hline Sucrose & - & + & + & + & + & + \\
\hline Lactose & - & - & + & + & + & - \\
\hline Arabinose & - & + & - & - & + & - \\
\hline Raffinose & - & - & Nil & + & - & - \\
\hline Salicin & - & - & - & + & Nil & - \\
\hline Glycerol & + & - & - & + & - & + \\
\hline
\end{tabular}

Where: + = Positive; - = Negative; Nil= not performed

The various Bacillus species identified were subjected to preliminary screening to ascertain their potential to produce biosurfactant using the following indicators: haemolytic activity, oil collapse method, emulsification index and oil spreading assays (Table 2). The Haemolysis test 
results showed that sixteen (16) of the isolates exhibited beta haemolysis ability while four (4) were non- Beta haemolytic organisms. The haemolytic reaction shown by the Bacillus species isolated in this study is characteristic of $\beta$-haemolysis. The high level of $\beta$-haemolytic Bacillus species observed in this study could be attributed to the growth of the isolates on hydrocarbon contaminated soils. According to Nwaguma et al. (2016), the presence of hydrocarbons in microbial environments induces production of surface-active compounds by the microbes inhabiting the environment. Nevertheless, studies had shown that biosurfactant-producing microorganisms are naturally present not only in hydrocarbonpolluted soils but also in organic matter suitable for the growth of diverse organisms (Nwaguma et al., 2016). Anaukwu et al. (2015) and Okore et al. (2017) studied microbial diversity of biosurfactant- producing bacteria from contaminated environmental samples (water and soil) using cultural methods and indicated the presence of biosurfactants. The positive drop collapse assay result of the Bacillus species points to the extracellular production of biosurfactant and its surface-active nature (Das and Chandran, 2011). Said et al. (2015) had also reported that Bacillus species recording a negative drops-collapse test were unable to produce biosurfactant. The findings in this study is similar to the work of Shoeb et al. (2015) who showed a positive drop-collapse test in Bacillus species. As reported by Batiata et al. (2006), in the presence of surfactant, a drop of supernatant from a pure culture of Bacillus species spreads over a hydrophobic surface as the interfacial tension between the droplet and the hydrophobic surface is reduced. In contrast, the droplet remains beaded or rounded in the absence of surfactant, as the polar water molecules are repelled from the hydrophobic surface (Batiata et al., 2006).

The Bacillus isolates showed varying oil displacement zone formation. An oil spreading test of Bacillus species showed that Bacillus thuringiensis (PO7(3)C) produced the highest oil spreading or displacement ability of $6.60 \mathrm{~mm}$. The oil spreading observed indicated that the broth used has surface activities, hence, the larger the spreading diameter, the higher the surface activity (Chandran and Das, 2010). A similar result was shown in the work of Adnan et al. (2015) which gave oil displacements zone value of $25 \mathrm{~mm}$. Nur and Mohammed (2015) showed $3.6 \mathrm{~mm}$ oil spreading by Bacillus thuringiensis on crude oil. This study is in contrast with the work of Rabah and Bello (2015) which showed that Bacillus thuringiensis displaced vegetable oil by $18 \mathrm{~mm}$ and Bacillus licheniformis displaced the oil by $20 \mathrm{~mm}$. The variation in the results of the previous studies and the present study could be attributed to the variety of oils used by the researchers in the oil spreading assay.

Emulsification activities determine productivity of bioemulsifiers (Bonilla et al., 2005). In this study, kerosene was used as the hydrophobic substrate. Emulsification activity of the kerosene oil substrate revealed biosurfactant synthesis by the Bacillus species. The results of emulsification index shown in Table 2 reveal variations in the emulsification potentials of the various Bacillus species studied. The variation implies that the different isolates possess different degrees of biosurfactant activity and biosurfactants are species- specific as has been previously reported (Aperna et al., 2012). The variation can also be attributed to differences in their habitats and physicochemical compositions from which they were isolated. The results obtained from emulsification index study in the current work is similar to the finding of Satpute et al. (2008) who showed emulsification index of $78 \%$ by Bacillus cereus using kerosene. Ainon (2013) showed an emulsification index value of $68 \%$ with Pseudomonas sp. isolated from hydrocarbon contaminated soil. One of the characteristics of biosurfactants is their potential to produce emulsion with oil. The ability of the isolates obtained in the present study to produce biosurfactant which emulsifies kerosene suggests that they can be used industrially as emulsifying agents. The ability of the Bacillus species to produce biosurfactant was further corroborated by reduction in surface tension. Decrease in surface tension indicates the ability of the isolates to produce biosurfactant with surface activity. Anaukwu et al. (2015) demonstrated similar results. They obtained Bacillus species that lowered the surface tension to below $40 \mathrm{mN} / \mathrm{m}$ (Table 2). The screening parameters selected in this study were consistent with previous works by Anaukwu et al. (2015) and Sidkey et al. (2016). Kiran et al. (2010) recommended that more than one 
Walter et al. /Nig. J. Biotech. Vol. 37 Num. 2: 165-176 (Dec 2020)

selection method should be used during preliminary tests to detect biosurfactant producers. The selection of these techniques was based on their user-friendliness, cost effectiveness, quick implementation and use of relatively commonly available equipments.

Table 2: Biosurfactant screening of Bacillus sp. isolated from contaminated soils in Makurdi

\begin{tabular}{|c|c|c|c|c|c|}
\hline Isolates & $\begin{array}{l}\text { Surface } \\
\text { Tension } \\
(\mathrm{mN} / \mathrm{m})\end{array}$ & $\begin{array}{l}\text { Oil } \\
\text { Spreading } \\
\text { (mm) }\end{array}$ & $\begin{array}{l}\text { Emulsification } \\
\text { Index }(\%)\end{array}$ & Drop Collapse & $\begin{array}{l}\text { Beta } \\
\text { Haemolysis }\end{array}$ \\
\hline $\mathrm{PO}(3) \mathrm{C}$ & $47.02^{\text {cd }}$ & $6.60^{a}$ & $54.27^{f}$ & + & + \\
\hline $\mathrm{PO} 4(3) \mathrm{A}$ & $41.41^{f}$ & $3.17^{e}$ & $57.24^{d}$ & + & + \\
\hline $\mathrm{HC2}$ (4)B & $54.08^{b}$ & $3.03^{\text {ef }}$ & $45.22^{h}$ & + & + \\
\hline $\mathrm{HC10}(5) \mathrm{C}$ & $40.33^{f}$ & $5.57^{b}$ & $55.71^{\text {def }}$ & + & + \\
\hline $\mathrm{HC} 3(4) \mathrm{C}$ & $48.47^{\mathrm{cd}}$ & $4.97^{c}$ & $50.53^{9}$ & + & + \\
\hline $\mathrm{HC} 4(4) \mathrm{A}$ & $43.42^{\text {ef }}$ & $5.00^{c}$ & $57.15^{d}$ & + & + \\
\hline MS1(3)C & $40.59^{f}$ & $6.40^{a}$ & $55.89^{\text {def }}$ & + & + \\
\hline MS9(3)C & $49.05^{c}$ & $5.67^{b}$ & $50.70^{9}$ & + & + \\
\hline MS1(3)B & $35.42^{\mathrm{g}}$ & $6.77^{a}$ & $61.68^{c}$ & + & + \\
\hline MS4(3)C & $41.63^{f}$ & $4.37^{d}$ & $56.97^{\mathrm{de}}$ & + & + \\
\hline MS9(3)B & $42.54^{\text {ef }}$ & $4.93^{c}$ & $55.44^{\text {ef }}$ & + & + \\
\hline RT9(4)B & $43.63^{\text {ef }}$ & $6.57^{a}$ & $56.65^{\text {de }}$ & + & + \\
\hline RT9(4)C & $49.83^{c}$ & $4.77^{\mathrm{cd}}$ & $51.39^{9}$ & + & + \\
\hline $\mathrm{ABT}(5) 3 \mathrm{~B}$ & $34.10^{g}$ & $5.80^{b}$ & $65.48^{b}$ & + & + \\
\hline $\mathrm{HC} 4(4) \mathrm{B}$ & $69.98^{a}$ & $3.10^{\mathrm{ef}}$ & $20.08^{j}$ & - & - \\
\hline RT1(3)A & $68.71^{a}$ & $2.57^{\mathrm{fg}}$ & $20.80^{i}$ & - & - \\
\hline MS1(3)D & $45.68^{\text {de }}$ & $5.83^{b}$ & $50.92^{\mathrm{g}}$ & + & + \\
\hline RT6(4)D & $0.00^{\mathrm{i}}$ & $0.00^{h}$ & $0.00^{1}$ & - & - \\
\hline RTIO(3)E & $0.00^{i}$ & $2.13^{\mathrm{g}}$ & $16.44^{k}$ & - & - \\
\hline $\mathrm{RT7}(4) \mathrm{B}$ & $30.26^{\mathrm{h}}$ & $5.87^{b}$ & $76.25^{a}$ & + & + \\
\hline SE & 1.06 & 0.18 & 0.53 & & \\
\hline
\end{tabular}

Means on the same column with the same superscript do not differ significantly from each other $(P=0.05)$. Where: SE = Standard error; $+=$ Positive; $-=$ Negative

The molecular characterization of the obtained sequences revealed $95.6-100 \%$ similarity with deposited sequences in the GenBank (Table 3). This is similar to the study of Chung et al. (2008); Fateha et al. (2016); Plaza et al. (2017) where three different Bacillus species: Bacillus subtilis, Bacillus thuringiensis and Bacillus licheniformis (KP9) were screened for the presence of srfAA of surfactin synthetase using PCR. The Bacillus isolates investigated for the $\operatorname{SrfA} A$ gene showed possible relationships among the organisms based on the clustering on the Phylogenetic tree (Figure 1).

The Bacillus species that showed positive results during screening were investigated for the presence of the srfAA gene using specific primers. The results showed amplification of SrfAA gene fragments in seven Bacillus isolates. These srfAA -positive isolates were found to belong to the following six species of Bacillus. $B$. subtilis, $B$. cereus, and $B$ licheniformis, $B$ thuringiensis and Lysinibacillus fusiformis. Porob et al. (2013) and Fateha et al. (2016) also used the same set of primers in their previous works to amplify the surfactin gene.

Over time, contaminated soils have been proven to be a promising environment to discover microorganisms with novel capabilities. Screening of microbes from contaminated areas for the presence of SIfAA gene revealed the 
biosurfactant production activity of Bacillus isolates . In this study, we were successful in amplifying the genes responsible for biosurfactant production from 7 of 20 different Bacillus species from contaminated soil samples.
Although some of the isolates showed biosurfactant production ability and have been earlier reported to possess the srfAA specific gene, others showed no PCR band with the PCR primers used in the present study.

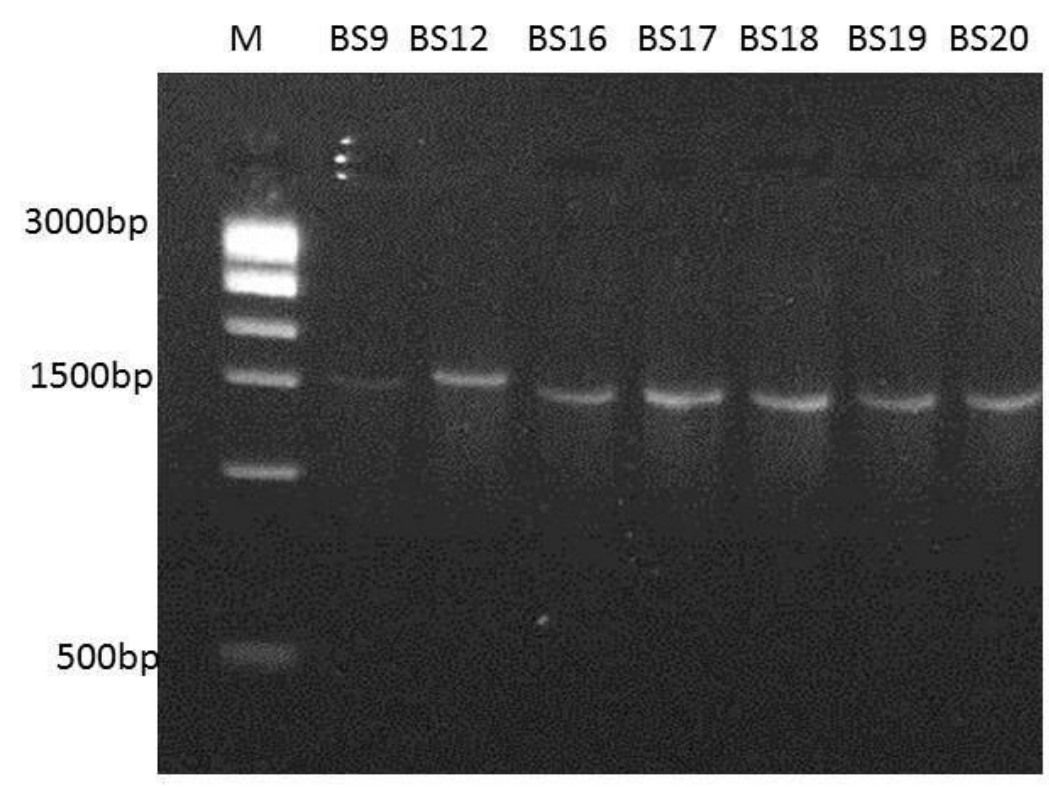

16S: $\mathrm{M}$ is $1 \mathrm{~kb}$ molecular weight ladder

Plate I: Gel electrophoresis result of PCR amplification for different Bacillus species isolates. The DNA fragments form a band on the gel at a location corresponding to 1500 base pair (bp) of the DNA ladder 
Walter et al. /Nig. J. Biotech. Vol. 37 Num. 2: 165-176 (Dec 2020)

Table 3: Genbank Homologs of Bacillus Bacterial Isolates from Different Contaminated Soil Samples Used in This Study for Screening of the SrfAA

\begin{tabular}{|c|c|c|c|c|}
\hline Isolates Code & PCR Code & Identity & \%Pairwise & Accession number \\
\hline RT7(4)B & BS1 & Bacillus subtilis strain $H k b-1$ & 95.6 & KP716963.1 \\
\hline $\mathrm{HC} 2(4) \mathrm{B}$ & BS2 & Bacillus thuringiensis strain C15 & 99.2 & СР021436 \\
\hline $\mathrm{HC} 10(5) \mathrm{C}$ & BS8 & Lysinibacillus fusiformis strain PgKB25 & 99.3 & MK559566 \\
\hline $\mathrm{HC} 4(4) \mathrm{A}$ & BS9 & Bacillus cereus strain $A 1$ & 97.8 & СР015727 \\
\hline $\operatorname{MS1}(3) \mathrm{C}$ & BS10 & Lysinibacillus fusiformis strain $A 1$ & 99.3 & MK559526 \\
\hline MS1(3)B & BS12 & Bacillus cereus strain BHU1 & 97.8 & СР023727 \\
\hline MS4(3)C & BS13 & Bacillus cereus strain $A 1$ & 97.2 & СР015727 \\
\hline PO4(3)A & BS14 & Bacillus thuringiensis strain c25 & 96.5 & СР022345 \\
\hline PO7(3)C & BS15 & Bacillus cereus strain $H B L-A I$ & 98.1 & СР023245 \\
\hline $\mathrm{HC} 3(4) \mathrm{C}$ & BS16 & Bacillus cereus strain $\mathrm{K} 3$ & 97.5 & MK530096 \\
\hline RT9(4)C & BS17 & Bacillus cereus strain GX S-2 & 96.9 & KU879246 \\
\hline Abt(5)3B & BS18 & Bacillus licheniformis strain APBSWPTB159 & 96.8 & MG733632 \\
\hline MS9(3)C & BS19 & Bacillus cereus strain 35 & 97.2 & KX058475 \\
\hline MS9(3)B & BS20 & Bacillus thuringiensis strain T0139 & 99.7 & CP035737 \\
\hline
\end{tabular}


BS1 (Bacillus subtilis Hkb-

BS8 (Lysinbacillus fusiformis A1)

BS10 (Lysinbacillus fusiformis

BS19 (Bacillus cereus 35)

BS17 (Bacillus cereus GXS-2)

BS20 (Bacillus thuringiensis

BS2 (Bacillus thuringiensis

BS18(Bacillus licheniformis

BS12 (Bacillus cereus

BS15 (Bacillus cereus HBL-

BS13 (Bacillus cereus A1)

BS14 (Bacillus thuringiensis

BS16 (Bacillus cereus K3)

BS9 (Bacillus cereus A2)

Figure 1: Phylogenetic tree of fifteen Bacillus species isolated from contaminated soils. The tree was constructed using Neighbour-joining method based on evolutionary distances computed using the maximum composite likelihood method representing the relationship between the srfAA gene sequences. All the reference sequences used for the construction of the tree, with their corresponding accession numbers, were retrieved from GenBank. 


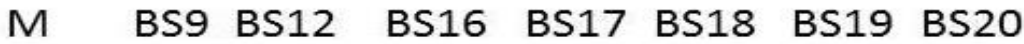

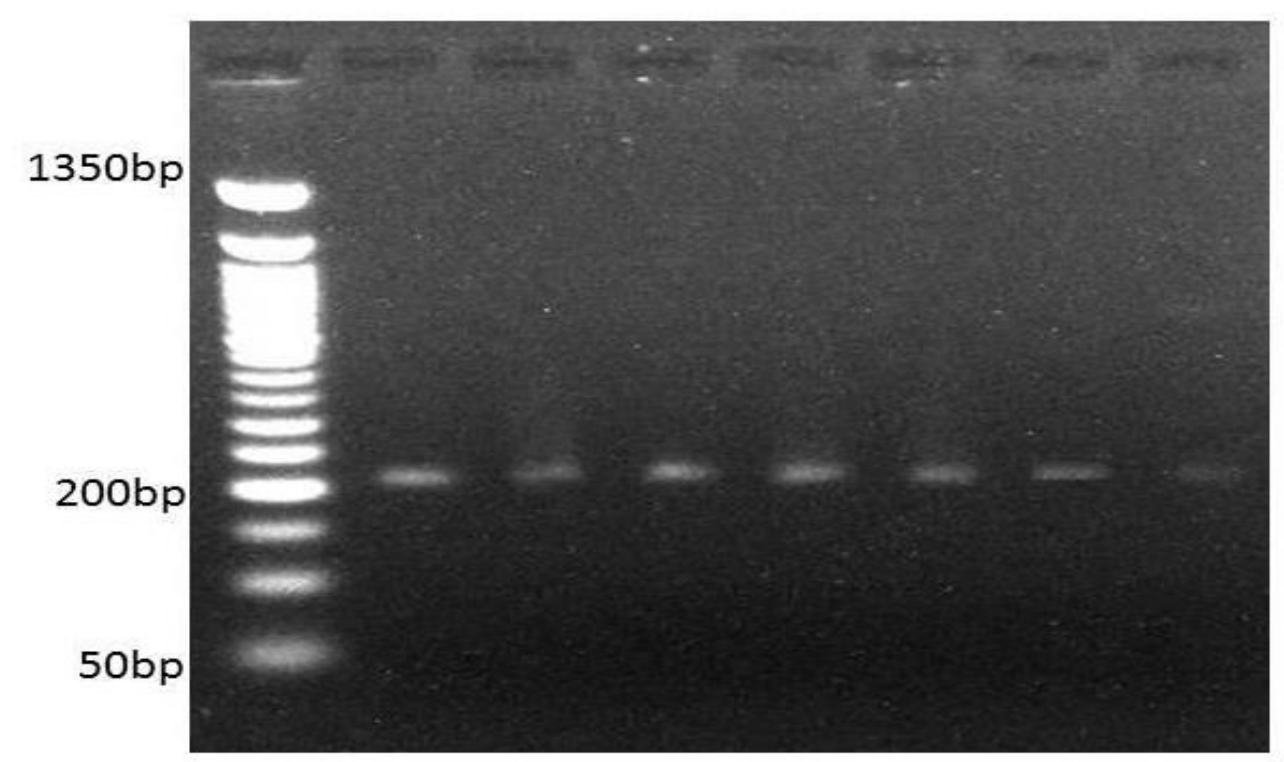

Plate II: Gel electropherogram for sIfAA amplification from the different Bacillus species isolated. The result indicated 200bpDNA amplicons

\section{Conclusion}

Based on the present study , contaminated soils in Makurdi metropolis would be an ideal source of biosurfactant- producing Bacillus species. This study revealed that the contaminated soil samples used harbour the following species of Bacillus: Bacillus licheniformis, Bacillus subtilis, Bacillus cereus, Bacillus thuringiensis and Lysinibacillus fusiformis. Bacillus subtilis strain Hkb-1(RT7(4)B) exhibited the highest ability to synthesize biosurfactant with $76.25 \%$ emulsification index.

The presence of SIAAA gene in $23.6 \%$ of the total Bacillus species isolated proves that the contaminated soils are huge sources for harnessing biosurfactant- producing Bacillus species and hence the isolates may be vital for the biosynthesis of this bioactive compound having wide applications in different fields.

\section{References}

Adnan, H., Abbas, Shurooq, M., Wsain, D., Auday, A. A. and Shahlaa. K. F. (2015). Using of Biosurfactant and Bacterial Enzymes for Treatment of the Oily Polluted Soils. Inter. J. Adv. Res. 3(5): 741-748.
Ainon, H., Noramiza, S. And Shahidan, R. (2013). Screening and Optimization of Biosurfactant Production by the Hydrocarbon-Degrading Bacteria. Sains Malay. J. 42(5): 615-623.

Akintokun, A.K.1., Adebajo, S.O.1. and Akinremi, C.A. (2017). Potential Biosurfactant-Producing Bacteria from Pharmaceutical Wastewater Using Simple Screening Methods in South-West, Nigeria. Appl. Env. Res. 39 (2): 41-54.

Anaukwu, C. G., Ekwealor, A. I., Ezemba, C.C., Anakwenze, V. N., Okafor, U. C. and Archibong, E. J. (2015). Pseudomonas monteilii and Citrobacter murliniae, Biosurfactant-Producing Bacteria Isolated from Nigerian Soil. Brit. Microb. Res. J. 10(1): 1-9.

Anitha, J., Jeyanthi, V. And Ganesh, P. (2015). Production and Characterization of Biosurfactant by Bacillus and its Applicability in Enhanced Oil Recovery. Inter. J. Adv. Res. in Biol. Sci. 2(5): 716.

Aparna, A., Srinikethan, G. and Smitha, H. (2012). Isolation, Screening and Production of Biosurfactant by Bacillus Clausii 5B. Res. in Biotech. 3(2):49-56. 
Arezoo, D. and Salmah, B. I. (2015). Bioenrichment of Waste Crude Oil Polluted Soil: Amended with Bacillus $139 S I$ and Organic Waste. Inter. J. Env. Sci. and Dev. 6(4):241-245.

Balogun, S.A. and Fagade, O.E. (2010). Emulsifying Bacteria in Produce Water from Niger Delta, Nigeria. Afri. J. Microb. Res. 4 (9): 730734.

Batiata, S., Mountear, A. and Amonm, F. (2006). Isolation and Characterization of Biosurfactant/Bioemulsifier-Producing Bacteria from Petroleum Contaminated Sites. Bio Resour. Tech. 97(6): 868-875.

Bonilla, M., Olivaro, C., Corona, M., Vazquez. A. and Soubes, M. (2005). Production and Characterization of a New Bioemulsifer from Pseudomonas putida ML2. J. Appl. Microb. 98: 456-463.

Chung, S., Kong, H., Buyer, J.S., Lakshman, D.K., Lydon, J., Kim, S. D. and Roberts, D.P. (2008). Isolation and Partial Characterization of Bacillus subtilis ME488 for Suppression of Soil Borne Pathogens of Cucumber and Pepper. J. Appl. Microb. Biotech. 80: 115-123.

Cosmina, P., Rodriguez, F., De Ferra, F., Grandi, G., Perego, M., Venema, G. and Von Sinderen, D. (1993). Sequence and Analysis of the Genetic Locus Responsible for Surfactin Synthesis in Bacillus subtilis. J. Mole. Microb. 8: 821-31.

Das, N. and Chandran, P. (2011). Characterization and Sophorolipid Biosurfactant Produced by Yeast Species Grown on Diesel Oil. Inter. J. Sci. Ana Nat. 2(1):63-71.

Desai, J.D. and Banat, I.M. (1997). Microbial Production of Surfactants and their Commercial Potential. J. Microb. Mol. Bio. Rev. 61: 47-64.

El-Shahawy, M.R. (2014).Biosynthesis Of Biosurfactant by Egyptian Local Bacterial Isolates Using Different Agricultural Wastes. J. Nucl. Tech. in Appl. Sci. 2(4): 409-417.

El-Sheshtawy, H.S., Aiad, I., Osman, M.E., AboElnasr, A.A., And Kobisy, A.S. (2013). Comparative Study of Biosurfactants Production by Bacillus licheniformis and Candida albicans for
Microbial Enhanced Oil Recovery. J. Appl. Sci. Res. 9(8):4877-4883.

Fateha, I., Zahid, M. and Amer, J. (2016). PCR Based Screening for Srfaa ORF1 from Local Bacillus Species. Inter. J. Chem. and Biochem. Sci. 9:1-9.

Hasham, M.M, Mohamed A.F and Mohamed, N.H. (2012). Production of Biosurfactant from Certain Candida Strains Under Special Conditions. Res. 4(7):39-55.

Ismail, W., Al-Rowaihi, I. S., Al-Humam, A. A., Hamza, R. Y., El Nayal, A. M. and Bououdina, M. (2013). Characterization of a lipopeptide biosurfactant produced by a crude-oil-emulsifying Bacillus sp. I-15. Inter. J. Bio-deteri. and Biodegrad. 84:168-178.

Kiran, G.S., Thomas, T.A. and Selvin, J. (2010). Production of a New Glycolipid Biosurfactant from Marine Nocardiopsis Lucentensis MSA04 in SolidState Cultivation. Colloids, 78:8-16.

Nakano, M.M., Corbell, N., Besson, J. and Zuber, P. (1992) Isolation and Characterization of Sfp: A Gene That Functions in the Production of the Lipopeptide Biosurfactant, Surfactin, In Bacillus subtilis. Mole. Gen. Genet., 232:313-321.

Noparat, P., Maneerat, S. and Saimmai, A. (2014). Application of biosurfactant from Sphingobacterium spiritivorum AS43 in the biodegradation of used lubricating oil. Applied Biochemistry Biotechnology, 172:3949-3969

Nur, H. S. and Mohammed, H. I. (2015). Isolation and Screening of Biosurfactant-Producing Bacillus Subtilis in Local Traditional Fermented Foods. Proceedings of Tenth. The IIER Inter. Conf. Kuala Lumpur, Malaysia.

Nwaguma, I.V., Chioma, B. C. and Gideon, C. O. (2016). Isolation, Screening and Identification of Biosurfactant-Producing Bacteria from Hydrocarbon-Polluted and Pristine Soils within Ogoniland, Nigeria. Brit. Microb. Res. J. 15(4): 111.

Okore, C. C., Nwaehiri, L. U., Mbanefo, O.N., Ogbulie, T.E., Ugenyi, A. U., Ogbuka, I.B., Ejele, I.E. And Okwujiako, I. A. (2017). Study on 
microbial Diversity of Biosurfactant Producing Bacteria from Contaminated Enviromental fSamples. Inter. J. Adv. Res. 5(6): 1387-1396.

Okore, C.C., Mbanefo, O.N., Onyekwere, B.C., Onyewenjo, S. and Abba-Father, C.A.M. (2013). Isolation and Characterization of Biosurfactants Producing Bacteria from Oil Polluted Soil. J. Nat. Sci. Res. 3(5):119-122.

Onyeagba, A. (2004). Laboratory Guide for Microbiology. Crys. Publ. 1:95-110.

Parthipan, P., Preetham, E., Machuca, L.L., Rahman, P.K.S.M., Murugan, K. and Rajasekar, A. (2017). Biosurfactant and Degradative Enzymes Mediated Crude Oil Degradation by Bacterium Bacillus Subtilis A1. Front. Microb. 8: 1-14.

Pfeifer, B.A., S.J. Admineral, H. Gramajo, D.E. Cane, C. and Khosla, C. (2001). Biosynthesis of Complex Polyktidesin a Metabolically Engineered Strain of E. Coli. SCi. J. 291: 1790-972.

Płaza, G. J., Chojniak, K., Rudnicka, K., Paraszkiewicz, P. and Bernat, P. (2017). Detection of Biosurfactants in Bacillus Species: Genes and Products Identification. J. Appl. Microb. 34:(1)23-29.

Porob, S., Nayak, S., Fernandes, A., Padmanabhan, P., Patil, B.A., Meena, R.M. and Ramaiah, N. (2013). PCR Screening for the Surfactin (Sfp) Gene in Marine Bacillus Strains and its Molecular Characterization from Bacillus Tequilensis NIOS11. Turk. J. Bio. 37: 212-221.

Rabah, A. B. and Bello, H. (2015). Production and Characterization of Biosurfactants from Abattoir Wastewater. J. Bio. Agric. Healthcare, 5:1-7.

Roongswang, N., Thanjyavarn, J., Thanjyavarn, S., Kamayam, T., Haruki, M., Imanaka, T., Morikawa, M. and Kanaya, S. (2002). Isolation and Characterization of Halotolerant Bacillus subtilis BBK-1 which produces three Kinds of Lipopeptides, Bacillomycin L, Plipastin and Surfactin. J. Extremoph. 6: 499-504.

Said, B.H., Latifa, S., Abdeljelil, G., and Abderrazak, M. (2012). Screening of Potential Biosurfactant Producing Bacteria Isolated from
Seawater Biofilm. Afri. J. Biotech. 11(77): 1415314158.

Saisa-Ard, K., Maneerat, S. and Saimmai, A. (2013). Isolation and Characterization of Biosurfactants producing Bacteria Isolated from Palm Oil Industry and Evaluation for Biosurfactants Production using Low-Cost Substrates. J. Biotech. Comput. Biol. Biotech. 94(3):275-284.

Satpute, S. K., Bhawsar, B. D., Dhakephalkar, P. K., and Chopade, B. A. (2008). Assessment of Different Screening Methods for Selecting Biosurfactant Producing Marine Bacteria. Ind. J. Mar. Sci. 37(3), 243-250.

Seema, D. and Nakuleshwar, D. J. (2012). Isolation of Biosurfactant-Producing Marine Bacteria. Afri. J. Env. Sci. Tech. 6(6):263-266.

Shoeb, E., Nuzhat, A., Jameela, A., Uzma, B., Khaizran, S., Faiza, A. A., Maheen, W., Samina, I., Nimrah, A., Qurat. U. A. S., Roaunq, B., Saba, B., Saema, K., Sidra, K., Shahid, H., Bashir, A. and Maqsood, A. A. (2015). Screening and Characterization of Biosurfactant-Producing Bacteria Isolated from the Arabian Sea Coast of Karachi. Turk. J. Bio. 39: 210-216.

Sidkey, N.M., Mohamed, H.F. and Elkhouly, I.H. (2016). Evaluation of Different Screening Methods for Biosurfactant Producers Isolated from Contaminated Egyptian Samples Grown on Industrial Olive Oil Processing Waste. Brit. Microb. Res. J. 17(4): 1-19.

Sreethar, S., Varadharajan, K., Arockiasamy, S. P., Ganesan, S., Asit, B. M. and Arumugam, G. (2014). Phylogenetic Framework and Biosurfactant Gene Expression Analysis of Marine Bacillus Spp. of Eastern Coastal Plain of Tamil Nadu. Inter. J. Bacterio. 86:4-9.

Tambekar, D.H.I. and Gadakh1, P.V. (2013). Biochemical and Molecular Detection of Biosurfactant Producing Bacteria from Soil. Inter. J. Lifesci. Biotech. Pharma Res. 2:1-8. 